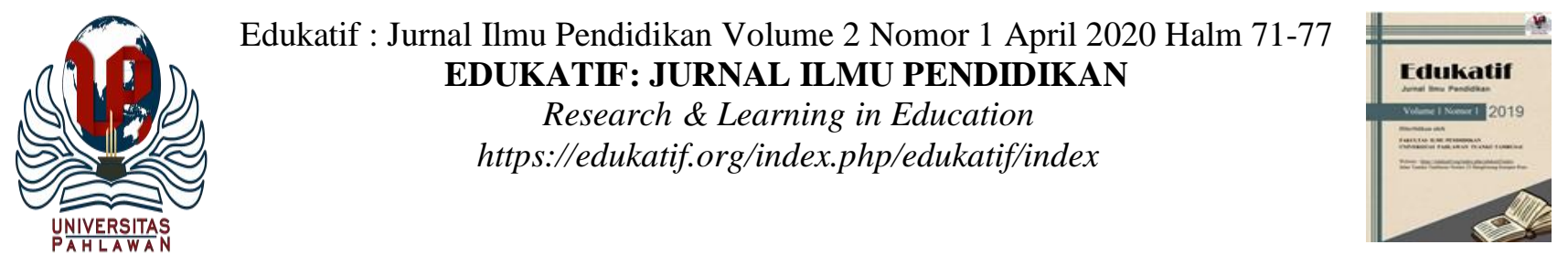

\title{
PERAN GURU TERHADAP MENGOPTIMALKAN UNIT KESEHATAN SEKOLAH UNTUK MELAKUKAN PENCEGAHAN COVID-19
}

\author{
Indra Murti Wulandari ${ }^{1}$ \\ Universitas Kristen Satya Wacana, Falkutas Keguruan dan Ilmu Pendidikan ${ }^{1}$ \\ e-mail: $\underline{\text { indrmrtw@gmail.com }}{ }^{1}$
}

\begin{abstract}
Abstrak
Pendidikan adalah usaha sadar dan terencana untuk membentuk manusia yang beradab. Pendidikan sangat penting bagi suatu bangsa agar pembangunan Nasional dapat berjalan dengan baik dan maksimal sesuai Pancasila dan UUD 1945. Dalam pendidikan saat ini memiliki masalah yaitu pandemik COVID-19 yang menyebabkan pendidikan menjadi semakin tidak memiliki waktu yang optimal dalam memberikan pembelajaran secara tatap muka untuk peserta didik. COVID-19 adalah penyakit yang disebabkan oleh infeksi virus SARS-CoV-2 suatu kelompok virus disebabkan oleh jenis coronavirus yang dapat menyebabkan penyakit pada hewan atau manusia, pertama kali ditemukan wabah penyakit ini di kota Wuhan, di Provinsi Hubei Cina pada Desember 2019. COVID-19 ini sangat mempengaruhi kehidupan manusia terutama dalam bidang pendidikan dan kesehatan. Dalam pendidikan di Indonesia memiliki unit kesehatan sekolah (UKS) yang sangat berpengaruh dalam kesehatan disekolah upaya pencegahan COVID-19 saat ini. UKS memiliki pengertian sebagai suatu usaha yang dilakukan sekolah untuk menolong murid maupun warga sekolah yang sakit dikawasan lingkungan sekolah. Bidang pendidikan terutama peran guru memiliki cara dalam pencegahan COVID-19 ini dengan cara menyediakan materi pembelajaran secara online. Dengan demikian kesehatan diri harus dijaga salah satunya dengan cara yang sudah dianjurkan oleh pemerintah yang diberi nama "Social Distancing” untuk menghambat penyebaran virus COVID-19 ini.
\end{abstract}

Kata Kunci: COVID-19, Peran Guru, Pendidikan,Unit Kesehatan Sekolah

\begin{abstract}
Education is a conscious and planned effort to shape civilized people. Education is very important for a nation that national development can work well and corresponding maximum Pancasila and the 1945 constitution. In education today has a problem that is the COVID-19 pandemic which causes education in increasingly does not have an optimal time in providing face to face learning for students. COVID-19 is a disease caused by a SARS-CoV-2 virus infection, a group of viruses caused by a type of coronavirus that can cause disease in animals and humans, the first time this outbreak was discovered in the city of Wuhan, in the Hubei district of Chinese in December 2019. COVID-19 give greatly impact human life, especially in the fields of education and health. Education in Indonesia, there is a school health clinic that is very influential in school health at the current COVID-19 prevention effort. The school health clinic has the understanding as an attempt by the school to help students who are sick in the school environment. In the field of education, especially the role of teachers has a way of preventing COVID-19by providing learning materials online. Thus, personal health must be maintained one of them in a way that has been recommended by the government which is named "Social Distancing" to inhibit the spread of the COVID-19 virus.
\end{abstract}

Keywords: COVID-19, Teacher Role, Education, School Health Clinic.

@Edukatif: Jurnal Ilmu Pendidikan 2020

$\triangle$ Corresponding author :

Address : Jawa Tengah

ISSN 2656-8063 (Media Cetak)

Email : indrmrtw@gmail.com

ISSN 2656-8071 (Media Online)

Phone : 


\section{PENDAHULUAN}

Menurut UU No.20 tahun 2003 Pendidikan adalah usaha sadar dan terencana untuk mewujudkan suasana belajar dan proses pembelajaran agar peserta didik secara aktif mengembangkan potensi dirinya untuk memiliki kekuatan spiritual keagamaan, pengendalian diri, kepribadian, kecerdasan, akhlak mulia, serta keterampilan, yang diperlukan dirinya, masyarakat, dan Negara. Pembangunan suatu negara tak lepas dari peran pendidikan, bangsa yang terdidik akan menjadikan bangsa yang besar sehingga pembangunan pun dapat berjalan dengan baik. Oleh karena itu peran pendidikan sangat penting dalam pencegahan pandemi COVID-19. Menurut World Health Organization (WHO) coronavirus adalah suatu kelompok virus yang dapat menyebabkan penyakit pada hewan atau manusia. Beberapa jenis coronavirus diketahui menyebabkan infeksi saluran nafas pada manusia mulai dari batuk pilek hingga yang lebih serius seperti Middle East Respiratory Syndrome (MERS) dan Severe Acute Respiratory Syndrome (SARS). Coronavirus jenis baru yang ditemukan menyebabkan penyakit COVID-19. COVID-19 adalah penyakit menular yang disebabkan oleh jenis coronavirus yang baru ditemukan, virus ini adalah penyakit jenis baru yang ditemukan terjadi wabah di Wuhan, Tiongkok, bulan Desember 2019.

Alih-alih sebagai wujud upaya guru dalam upaya mengoptimalkan pendidikan Menteri Pendidikan dan Kebudayaan, Nadiem Anwar Makarim memberikan isntruksi untuk segera mengoptimalkan unit layanan kesehatan diperguruan tinggi maupun sekolah dengan cara berkoordinasi dengan peayanan kesehatan setempat dalam pencegahan COVID-19. Namun diberbagai sekolah memiliki ruang UKS namun tidak pernah terurus sehingga bebrapa hal yang wajib ada di ruang UKS tersebut tidak tersedia, contohnya obat, minyak kayu putih.

Dilain sisi kesehatan diri sangat penting dalam situasi yang sangat darurat ini, untuk menjaga kesehatan diri guru dan peserta didik harus memperhatikan kesehatan diri masingmasing. dengan demikian pencegahan ini dapat dilakukan dengan cara yang telah dianjurkan oleh pemerintah yaitu social distancing, mencuci tangan, dan menggunakan masker saat berpergian. Berdasarkan beberapa masalah yang ditemukan karena peran guru dalam pencegahan COVID-19, penulis menjadi tertarik untuk mengangkat suatu judul yaitu "Peran Guru Terhadap Mengoptimalkan Unit Kesehatan Sekolah Untuk Melakukan Pencegahan COVID-19".

\section{METODE PENELITIAN}

Metode yang digunakan dalam artikel yang berjudul "Peran Guru Terhadap Mengoptimalkan Unit Kesehatan Sekolah Untuk Melakukan Pencegahan COVID-19” menggunakan pendekatan kepustakaan. Studi pustaka atau kepustakaan merupakan serangkaian kegiatan yang memuat metode pengumpulan data pustaka, membaca serta mencatat lalu mengolah bahan penelitian (Zed, 2003). Dalam penelitian pustaka hal-hal yang bukan dengan pengetahuan langsung di lapangan. Kedua, data pustaka harus siap pakai artinya penulis tidak harus melakukan penelitian langsung melainkan dengan melihat atau berhadapan dengan sumber data yang di pergunakan. Berdasarkan hal tersebut artinya pengumpulan data dilakukan dengan melakukan 
eksplorasi terhadap beberapa sumber data seperti jurnal, buku , dan dokumen-dokumen lain yang relevan (baik dalam bentuk cetak maupun elektronik). Penelitian ini bersifat kualitatif yang lebih mengutamakan penggalian, penemuan, serta penyampaian data yang dikumpulkan. Analisis yang digunakan bersifat deskriptif, teoritis dan filosofis.

\section{HASIL DAN PEMBAHASAN PENELITIAN}

\section{Apa Itu COVID-19?}

COVID-19 adalah penyakit yang disebabkan oleh infeksi virus SARS-CoV-2, pertama kali diidentifikasi di kota Wuhan, di provinsi Hubei Cina pada Desember 2019. COVID-19 telah menyebar ke berbagai negara di dunia, termasuk Indonesia. Jumlah kasus positif virus corona di Indonesia terus bertambah. COVID-19 sebelumnya dikenal sebagai Novel 201 Novel Coronavirus (2019$\mathrm{nCoV})$ penyakit pernapasan, sebelum Organisasi Kesehatan Dunia (WHO) menyatakan nama resmi sebagai COVID-19 pada bulan Februari 2020. World Health Organization (WHO) coronavirus adalah suatu kelompok virus yang dapat menyebabkan penyakit pada hewan atau manusia. Beberapa jenis coronavirus diketahui menyebabkan infeksi saluran nafas pada manusia mulai dari batuk pilek hingga yang lebih serius seperti Middle East Respiratory Syndrome (MERS) dan Severe Acute Respiratory Syndrome (SARS). Coronavirus jenis baru yang ditemukan menyebabkan penyakit COVID-19. COVID-19 adalah penyakit menular yang disebabkan oleh jenis coronavirus yang baru ditemukan, virus ini adalah penyakit jenis baru yang ditemukan terjadi wabah di Wuhan, Tiongkok, bulan Desember 2019. COVID-19 ini sampa sekarang masih belum ditemukan obat untuk menyembuhkan penyakit ini.

\section{Apa Itu Unit Kesehatan sekolah?}

Menurut Depkes RI adalah usaha kesehatan masyarakat yang dijalankan disekolah dengan peserta didik berserta lingkungan hidupnya sebagai sasaran utama, UKS merupakan wahana untuk meningkatkan kemampuan hidup sehat dan selanjutnya membentuk perilaku hidup sehat.

Unit kesehatan sekolah adalah salah satu wahana untuk mningkatkan kemampuan hidup sehat, yang pada gilirannya menghasilkan derajat kesehatan siswa yang optimal dan serta berperilaku hidup sehat. UKS memiliki pengertian sebagai suatu usaha yang dilakukan sekolah untuk menolong murid maupun warga sekolah yang sakit dikawasan lingkungan sekolah.

Jadi unit kesehatan sekolah atau UKS adalah ujung tombak dalam pemberdayaan kesehatan warga sekolah dalam melaksankan hidup sehat. Jika dalam lingkunngan sekolah tidak memiliki unit kesehatan sekolah maka sekolah itu tidak memperhatikan kesehatan warga sekolahnya.

\section{Dampak COVID-19 dalam Sekolah.}

Menurut United Nations Educational, Scientific and Cultural Organization (UNESCO) COVID-19 berdampak pada pendidikan sekitar 290,5 juta pelajar diseluruh dunia. UNESCO mengatakan bahwa meski bersifat sementara, penutupan sekolah 
berdampak pada berkurangnnya waktu pengajaran dan bisa berdampak pada prestasi. Apabila kondisi ini terus meningkat, maka dampak terhadap sektor pendidikan semakin meningkat. Dampak yang paling dikhawatirkan adalah dampak bagi peserta didik otomatis akan merasakan keterlambatan dalam proses pendidikan yang dijalaninya.

Dengan adanya kebijakan pemerintah untuk penundaan proses belajar secara langsung dapat mempengaruhi hak setiap peserta didik untuk mendapatkan layanan pendidikan yang layak. Sehingga pemerintah menetapkan dengan adanya proses pembelajaran yang dilakukan secara online.

\section{Kesehatan Diri}

COVID-19 ini telah menyebar seluruh Negara di dunia dan menyebabkan perubahan besar dalam gaya hidup dan bersosialisasi terhadap masyarakat. Dengan demikian dalam sektor pendidikan kesehatan diri sangat diperhatikan karena untuk menjaga imun kesehatan supaya tetap stabil. Alih-alih diperlukan beberapa hal yang dapat dilakukan peserta didik serta guru dalam menjaga kesehatan:

1. Sering cuci tangan dengan sabun dan air.

2. Tutup batuk dan bersin dengan tisu sekali pakai. Buang tisu setelah dipakai.

3. Menjaga jarak paling tidak satu meter.

4. Apabila kita berada diluar, WHO mengatakan penting untuk menghindari berjabat tangan dan menggunakan masker.

Kesehatan diri sangat penting dalam mempertahankan daya tahan tubuh, dengan cara makan yang teratur, tidur dengan cukup, minum vitamin $\mathrm{C}$, serta melakukan olahraga disetiap pagi.

\section{Peran Guru Dalam Mengoptimalkan Unit Kesehatan Sekolah}

Mendikbud memberikan intruksi kepada pihak sekolah terutama guru untuk memastikan ketersediaan sarana untuk cuci tangan pakai sabun dan alat pembersih sekali pakai (tisu) diberbagai lokasi satuan pendidikan. Selanjutnya, pihak sekolah diimbau untuk membersihkan ruangan dan lingkungan secara rutin, khususnya handel pintu, saklar lampu, papan tik, dan fasilitas lain yang sering terpegang oleh tangan.

Dengan adanya kebijakan pemerintah tersebut sebelum peserta didik memasuki aktivitas pembelajaran secara langsung guru dapat memberikan instruksi menggunakan masker saat memasuki lingkungan sekolah dan diwajibkan untuk melakukan cuci tangan menggunakan sabun dan air terlebih dulu, sehingga dengan dilakukannya hal tersebut dapat mencegah penyebaran COVID-19. Pihak sekolah diminta untuk menyediakan obat-obatan P3K sebagai sarana dan prasarana yang seharusnya terdapat di ruang UKS.

Peran guru dalam mengoptimalkan UKS dengan kondisi guru-guru melakukan WFH dapat dilakukan dengan cara mengkoordinasikan layanan kesehatan sekolah dengan layanan kesehatan setempat untuk melakukan penyemprotan desinfektan dilingkungan UKS dan sekolah yang dilakukan dalam seminggu sekali. 


\section{Pencegahan COVID-19 dilingkungan Sekolah}

Pada protokol area pendidikan, terdapat beberapa poin yang harus dilakukan oleh Dinas Pendidikan dan Dinas Kesehatan. Berikut rinciannya:

1. Sekolah melakukan koordinasi dengan Dinas Kesehatan setempat.

2. Menyediakan sarana untuk cuci tangan menggunakan air dan sabun di berbagai lokasi.

3. Menerapkan hidup sehat, seperti makan jajanan sehat dan membuang sampah pada tempatnya.

4. Membersihkan ruangan sekolah secara rutin dengan desinfektan.

5. Memberikan imbauan kepada warga sekolah yang sakit untuk mengisolasi diri dirumah dengan tidak melakukan kontak dengan orng lain.

6. Menunda kegiatan yang mengumpulkan banyak orang atau kegiatan di lingkungan luar sekolah, contohnya berkemah dan studi wisata.

7. Melakukan skrining awal berupa pengukuran suhu tubuh terhadap semua yang akan memasuki lingkungan sekolah.

8. Menggunakan masker dilingkungan sekoah. Apabila warga sekolah tidak memakai masker maka pihak sekolah harus mempunyai persediaan masker yang dapat digunakan dengan layak.

\section{SIMPULAN}

Pendidikan adalah usaha sadar dan terencana untuk mewujudkan suasana belajar dan proses pembelajaran agar peserta didik secara aktif mengembangkan potensi dirinya untuk memiliki kekuatan spiritual keagamaan, pengendalian diri, kepribadian, kecerdasan, akhlak mulia, serta keterampilan, yang diperlukan dirinya, masyarakat, dan negara. Namun dengan adanya pandemic COVID-19 memiliki dampak buruk dalam pendidikan sehingga peserta didik tidak dapat menjalankan proses pendidikan dengan layak. COVID-19 adalah penyakit yang disebabkan oleh infeksi virus SARS-CoV-2, pertama kali diidentifikasi di Kota Wuhan, di Provinsi Hubei Cina pada Desember 2019. Dengan demikian adanya virus tersebut peran guru dalam mengoptimalkan unit kesehatan sekolah atau UKS sangat berpengaruh bagi kesehatan lingkungan sekolah. Sehingga dengan adanya ini peran guru sangat berpengaruh dengan kesehatan sekolah untuk menjaga dan memberikan sarana dalam pencegahan COVID-19 ini. Jadi peran guru dalam mengoptimalkan layanan kesehatan sekolah dapat dilakukan dengan mengkoordinasikan dengan pihak layanan kesehatan setempat untuk melakukan penyemprotan desinfektan, memberikan fasilitas cuci tangan.

\section{DAFTAR PUSTAKA}

Depkes RI. (1992). Undang-Undang No. 23 Tahun 1992 Tentang Kesehatan. Jakarta: Depkes RI.

Dio Giovani Prasasti. (2020). UNESCO: Penutupan Sekolah Akibat Covid-19 Berdampak pada 290 Juta Pelajar di Dunia. Liputan 6.

DIREKTORAT JENDRAL PENCEGAHAN DAN PENGENDALIAN PENYAKIT. (2020). 
Peran Guru TerhadapMengoptimalkan Unit Kesehatan Sekolah untuk Melakukan Pencegahan COVID-19 - Indra Murti Wulandari

Pedoman Pencegahan dan Pengendlian Coronavirus Disease. Jakarta.

Febri Kurniawan. (2015). PELAKSANAAN

USAHA KESEHATAN (UKS) DISD

NEGERI 05 KALUMBUK

KECAMATAN KURANJI KOTA

PADANG. Pelaksanaan Usaha Kesehatan

Sekolah, 1-2.

Ishmah Atikah Winahyu. (2020, April 19). Mendikbud Imbau Sekolah Lakukan Upaya Pencegahan Covid-19.

Prasasti, Dio Giovani. (2020, Maret 06). Retrieved from

https://www.liputan6.com/health/read/419

5275/unesco-penutupan-sekolah-akibat-

covid-19-berdampak-pada-290-juta-

pelajar-di-dunia

UNDANG-UNDANG REPUBLIK INDONESIA.

(2003). Tentang Sistem Pendidikan

Nasional Undang-Undang Nomor 20

tahun2003. Jakarta.

World Health Organization. Pertanyaan dan Jawaban Terkait Coronavirus. South East Asia, Indonsia.

Zed. (2003). Metode Penelitian kepustakaan.

Jakarta: Yayasan Obor Indonesia. 